\title{
TEK and biodiversity management in agroforestry systems of different socio- ecological contexts of the Tehuacán Valley
}

\author{
Mariana Vallejo-Ramos ${ }^{1}$, Ana I. Moreno-Calles ${ }^{2}$ and Alejandro Casas $^{3^{*}}$
}

\begin{abstract}
Transformation of natural ecosystems into intensive agriculture is a main factor causing biodiversity loss worldwide. Agroforestry systems (AFS) may maintain biodiversity, ecosystem benefits and human wellbeing, they have therefore high potential for concealing production and conservation. However, promotion of intensive agriculture and disparagement of TEK endanger their permanence. A high diversity of AFS still exist in the world and their potentialities vary with the socio-ecological contexts. We analysed AFS in tropical, temperate, and arid environments, of the Tehuacan Valley, Mexico, to investigate how their capacity varies to conserve biodiversity and role of TEK influencing differences in those contexts. We hypothesized that biodiversity in AFS is related to that of forests types associated and the vigour of TEK and management. We conducted studies in a matrix of environments and human cultures in the Tehuacán Valley. In addition, we reviewed, systematized and compared information from other regions of Mexico and the world with comparable socio-ecological contexts in order to explore possible general patterns. Our study found from $26 \%$ to nearly $90 \%$ of wild plants species richness conserved in AFS, the decreasing proportion mainly associated to pressures for intensifying agricultural production and abandoning traditional techniques. Native species richness preserved in AFS is influenced by richness existing in the associated forests, but the main driver is how people preserve benefits of components and functions of ecosystems. Elements of modern agricultural production may coexist with traditional management patterns, but imposition of modern models may break possible balances. TEK influences decisions on what and how modern techniques may be advantageous for preserving biodiversity, ecosystem integrity in AFS and people's wellbeing. TEK, agroecology and other sciences may interact for maintaining and improving traditional AFS to increase biodiversity and ecosystem integrity while improving quality of life of people managing the AFS.
\end{abstract}

Keywords: Agroecology, Agroforestry systems, Sustainable management, TEK, Traditional management

\section{Background}

Transformation of natural ecosystems into intensive agricultural systems is among the main factors determining the high biodiversity loss throughout the world [1-5]. The expansion of agriculture and grassland areas is progressively growing. For instance, from 1980 to 2000, more than $55 \%$ of new agricultural fields were established in primary forests and nearly $28 \%$ in secondary forests [6]. Main efforts for biodiversity conservation have been

\footnotetext{
* Correspondence: acasas@cieco.unam.mx

${ }^{3}$ Instituto de Investigaciones en Ecosistemas y Sustentabilidad, UNAM, Universidad Nacional Autónoma de México (UNAM), Antigua Carretera a Pátzcuaro 8701, Morelia, Michoacán 58190, Mexico

Full list of author information is available at the end of the article
}

directed to decree natural reserves and protected areas, but these have only protected nearly $8 \%$ of the planetary forests [7]. Most of the natural protected areas are surrounded by or have inside them agricultural landscapes, commonly with environmental problems such as fragmentation, contamination by agrochemicals, illegal hunting and taming, soil erosion, among others $[8,9]$. Therefore, threatening of biodiversity within and outside protected areas are closely linked with socio-ecological processes occurring in landscapes at the surrounding area as well as inside them, including the matrix of agricultural and forest lands, and the management forms of agricultural systems [10-12]. 
In extent areas of the world, landscapes comprise agroforestry systems (AFS), which may play important roles for maintaining biodiversity and ecosystems integrity $[2,13]$. These systems are strongly supported by TEK, ecology, and agroecology; therefore, cooperation of TEK and ecological sciences in understanding and acting may be crucial for optimizing such a role of AFS in conservation programs while ensuring the wellbeing of people managing the systems.

AFS are complex systems combining wild and domesticated plant, animal, fungal and microorganisms components interacting, determining processes and emergent properties with beneficial consequences for both ecosystems and societies. These systems are designed and managed based on millenarian experiences of peoples throughout the world and are expressions of TEK and biocultural heritage. Traditionally, management of AFS include among their components trees, shrubs and herbs that are part of the natural forests, which confer them good capacities for conserving native species. Native species may be let standing, both adult plants and their sprouts, but also people may plant their propagules, or provide them special care [14-16].

Components of AFS are managed in systemic ways of land use [17-19] and practices could be reminiscences of the earliest forms of agriculture [20]; actually, several authors have postulated that agriculture derives from experiences of managing forests [21]. Current AFS are apparently the result of TEK based on centuries and even millennia of interactions between humans and nature, as well as knowledge and techniques resulting from such interactions. AFS synthesize the expression of ancient and deep biocultural interactions and TEK [22-25].

AFS have been studied from ecological sciences $[26,27]$, economic $[1,28]$, cultural and ethnoecological approaches [22, 25, 29], landscape analysis [4], among other disciplines. It is generally recognized that AFS integrate multiple wild and domesticated plant and animal components [25] in a coherent totality [30]. Crops and forest components are disposed in dynamic patches determining a high diversity of biophysical and socio-ecological processes [23] that favour the conservation and resilience of both components and functions [11, 31-34].

From an ecological perspective, at landscape level AFS may conform corridors that favour processes of dispersion of native flora and fauna, as well as maintenance of ecosystem functions that provide valuable environmental services. Among them, carbon sequestration, refuge of pollinators and natural predators of crop pests, reservoirs of propagules of plants for vegetation regeneration, soil conservation, and regulating factors of water, nutrient flows, and microclimates [2, 5, 35-38].
It has been documented that soils of AFS may be productive enough to sustain long term agricultural production [13, 17, 33], and are highly beneficial to maintain and improve production in areas with soils of low fertility and high or low humidity [37]. Presence of a cover of wild and domesticated plants favours availability of nutrients like nitrogen and absorption of nutrients in deep layers of soil [5, 37, 38].

AFS may favour maintenance of local and regional biodiversity [2, 23]. At regional level, the mosaic of agricultural and forest patches allows maintaining habitats, connectivity and gene flow among populations of flora and fauna species of conserved and fragmented areas [9, 26, 27, 33, 39-43]. At local scale, AFS may increase the floristic composition of both useful and not useful plants species [44], wild, weedy and domesticated plants [14, 21, 45], species from primary and secondary forests, and even plant species from several forest types of a region [16, 45-49]. All these practices significantly contribute to increase the species richness and diversity in AFS and the surrounding landscapes. In addition, some components of AFS, particularly trees, provide habitats favourable to other plant (e.g. epiphytes and hemi-parasitic plants) and animal species $[2,13,15]$. These processes, in turn, favour the coexistence and interactions among species, the stability and resilience, as well as a more sustainable productivity of the system than monocultures $[1,26,50,51]$.

AFS favour the potential of regeneration of forests disturbed by establishing of agricultural plots, and ease its restoration and that of the neighbouring systems. While conserving soil, water, animals dispersers of seeds, pollinators, and propagules of native plant species, AFS allow that fallow and abandoned agricultural plots are in good conditions for a faster succession and regeneration of natural ecosystems than those systems drastically transformed $[9,52,53]$.

AFS have been used based on the principle of multiple use of natural resources and functions of the systems, which has favoured the diversification of production systems for rural people subsistence $[22,28,54]$. The strategy of multiple use of resources prevail in rural peasant contexts, mainly where traditional agriculture is predominant, and where people have a close relationship with their land and perceive and know its multiple constituents, functions and interactions $[9,22]$. Such management strategy allows that AFS provide agricultural products along with forest resources used as construction, fuel, medicines, food, and other benefits $[1,26,47$, $49,55,56]$, which in turn may contribute to decrease pressure on resources extraction and clearing of forest areas. In addition, these have allowed generating monetary incomes to households in different regions [47, 48].

However their agroecological and biocultural importance, AFS are in high risk of disappearing. Among the 
factors that mainly endanger their existence, are the increasing social and economic pressures to intensify the production systems [25, 57], as well as loss of TEK associated to loss of traditional cultures, knowledge and techniques [22]. In addition, in Mexico, some governmental programs enhance removing vegetation cover in crop fields arguing that the remaining vegetation decreases agricultural production $[15,25]$. Some programs of governmental agencies and NGOs are careless, enhancing reforestation or AFS without considering local knowledge and opinions. These programs are generally unsuccessful $[28,54,58]$. Documenting TEK and management experience associated to AFS throughout the World is therefore a high priority of ethnobiological and agroecological research.

AFS have persisted throughout the time from the origins of agriculture. In the Tehuacán Valley, one of the earliest areas of agriculture of the New World [59], AFS predominate in the regional agricultural landscape $[15,47]$ and are most probably the earliest agricultural systems in that region, and probably in other areas of Mesoamerica. The hypotheses include the "hydro-horticulture" and the "streams horticulture" proposed by MacNeish [59], the forest disturbance model proposed by Smith [60], and the silvicultural origin model proposed by Casas et al. [14, 21]. A high diversity of AFS has been reported in the Tehuacán Valley, Mexico and other areas of the world [2, 5, 25, 27, 38, 41]. Their potentialities and limitations varying according to the ecological, cultural, social and economic contexts where they are practiced. Our study aimed to examine how social and ecological factors influence the management and structure of AFS systems. In particular, we directed our review to analyse how variable are AFS systems in different environmental contexts in Tehuacán Valley, how varies their capacity to conserve biodiversity, and which factors mainly influence the variation. We hypothesized that biodiversity harboured in AFS should be proportional to amount of diversity existing in the associated forests, as well as to the prevalence of TEK and management over intensive agricultural systems.

\section{Methods}

We conducted studies in a matrix of environments and human cultures in the Tehuacán Valley, central Mexico (Fig. 1) during nearly 10 years of studies comparing the vegetation composition of AFS and forests. Such studies have included AFS and different forest types in (1) dry areas (columnar cacti forests, thorn-scrub, and rosetophyllous forests), (2) tropical sub-humid and dry forests, which are associated to the rivers conforming a gradient from tropical dry forests to real tropical wet forests, and (3) temperate zones (oak-pine forests, sclerophyllous forests or mexical a type of Mediterranean-like vegetation). AFS systems may include two great groups of systems, those attached or close to peoples' houses (homegardens), and a great variety of systems apart from houses we call them in this study "field AFS". "Field AFS are not only different to homegardens in relation to the distance from houses but in relation to their function in production, extent, and capacity for maintaining natural vegetation. Our studies are now centred in "field AFS", and a comparison with homegardens will be discussed elsewhere. The analyses based on vegetation sampling, which allowed calculating the species richness, diversity and composition, relating density, frequency and biomass of each species in the sampling areas in both, forests and AFS. Plant composition was evaluated through the number of plant families, genera and species, considering all species and only native plant species. In forests we sampled square units of $500 \mathrm{~m}^{2}$ subdivided in five squares of $10 \mathrm{X} 10 \mathrm{~m}^{2}$. For sampling AFS we recorded individual plants of each species in areas of vegetation cover associated to agroforestry practices (remaining patches of forests inside agricultural plots, vegetation islands, vegetation fringes, isolated trees and living fences surrounding agricultural plots). In addition, we have documented general features of local human cultures, their agricultural knowledge and practices, emphasizing about the reasons why people maintain vegetation cover in their agricultural plots, the economic, ecological and agricultural benefits perceived by practicing AFS. We compared plant species richness and diversity among forests and AFS, as well as among AFS managed at different levels of intensity.

In addition, the studies included interviews to the owners of each agricultural plot that allowed documenting the type of management, land tenure, managed crops, the destiny of production (direct consumption, commercialization or interchange), total amount of production, use or not of machines, agro-chemicals, as well as strategies and techniques of management of natural vegetation maintained inside and around the plot, the purpose and reasons for maintaining the particular components.

Our study includes also information systematized from different regions of Mexico. During the last five years, we have compiled and systematized ecological, agronomic, human cultural and economic information on AFS of Mexico. Consequently, we have constructed the database "Biblioteca de Sistemas Agroforestales Tradicionales de México" (Library of Traditional Agroforestry Systems of Mexico), leaded by Ana Isabel Moreno-Calles, which can be consulted at https://www.zotero.org/groups/sistemas_agroforestales_tradicionales_de_méxico/.

We finally conducted an exhaustive review of literature on agroforestry systems from tropical, temperate and dry areas of the world, centring our attention on information comparing biodiversity conservation and ecosystem services in the context of traditional and intensive 

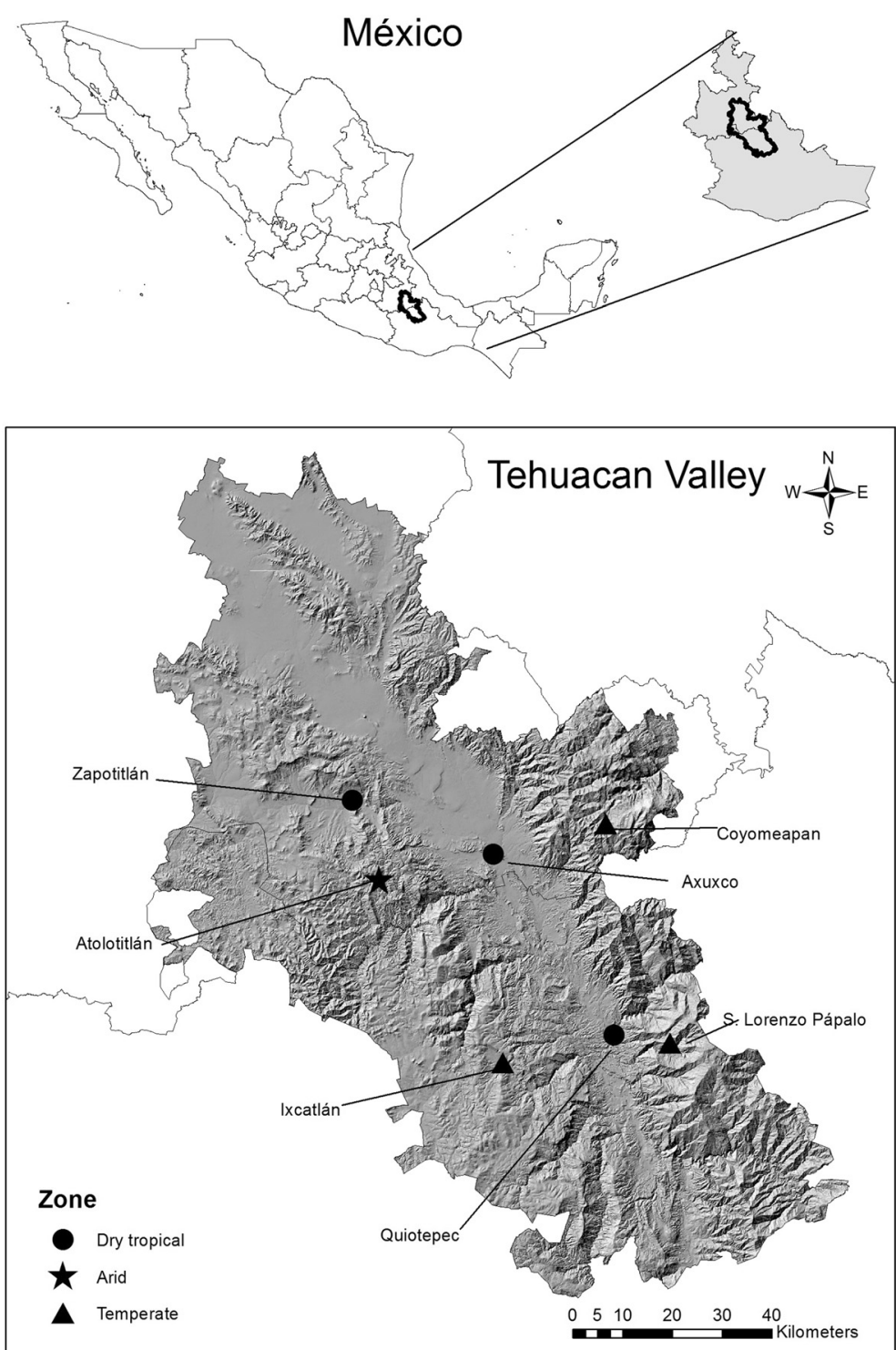

Fig. 1 Location of the Tehuacan Valley in Central Mexico. We indicate the names of the localities where the study was conducted and the type of environment studied

agricultural management in order to compare and analyse the context of our own information.

\section{Results}

\section{Agroforestry systems in tropical areas}

The most studied AFS are those located in tropical regions [2, 53, 61-64]. In the Tehuacán Valley, México, the tropical areas are located throughout the main permanent rivers and numerous streams of the region. There is a gradient of tropical vegetation, from tropical dry forests in the northern zone of the region to sub-humid vegetation represented by mezquitales in the central portion of the alluvial valleys to tropical wet forests in the lowest southernmost areas, where forests are really tropical rain forests surrounded by dry areas. Our studies documented mainly those sub-humid areas [49] that in lowland alluvial valleys. In these tropical forests zones, AFS associated to the multi-crop traditional system called milpa (commonly cultivating maize, beans and squashes) maintain 66 species of trees and shrubs, $81 \%$ of them being native species natives and representing nearly $38 \%$ of the woody flora of the forests surrounding the AFS (Tables 2 and 5). We found that even some endemic species may increase their abundance with agroforestry practices.

\section{Agroforestry practices}

In the tropical area, the most important agroforestry practices are semi-terraces, with fringes containing living 
fences and shrubby and herbaceous vegetation, where people maintain wild species. In some cases people move individual plants that are inside the plots to these fringes, which contribute to maintain soil and humidity and prevent erosion. The reasons for maintaining natural vegetation inside agricultural plots are mainly utilitarian, since most of them are used as food (fruits, the greens called quelites), medicinal, fodder, fuelwood and wood. However, it is also explicit the purpose of preventing soil erosion, maintaining soil fertility and having shade for resting during the agricultural work. In addition, people commonly say that they maintain trees and shrubs to ensure the specific hábitat of some other useful species. For instance, they maintain Parkinsonia praecox since the edible larvae cuchamá live on their stems and branches. Another example is the mezquite (Prosopis laevigata), which is maintained as support for pitahaya (Hylocereus undatus). Other non-utilitarian reasons are related with the beauty that plants provide to the plot, rituals, respect to use regulations, prestige or simply the recognition of the right of plants to live. We recorded 15 different reasons (Table 1).

In the humid tropical areas of Mexico, some outstanding AFS are found in south-eastern Mexico, where Ford and Nigh [65] and other authors identified that the shifting agriculture practiced by the Maya peoples involve the management of nearly 70 domesticated plants species that are cultivated in the fallow areas, together with useful wild plant species. These systems are associated to wetter tropical forests than those found in the Tehuacan Valley. Management techniques involve cultivation, transplantation and which increase their abundance artificially in the recovered forests. This practice appears to be ancient not only in the Maya region, and not only in tropical forests but in other Mesoamerican areas and vegetation types [14, 21]. Another group of tropical AFS is represented by the Kuojtakiloyan, a system studied in the Sierra Norte of the state of Puebla by Toledo and Moguel [66]. This system is also wetter than the tropical sub-humid forests that we documented in the Tehuacan

Table 1 Main reasons why people from different socio-ecological zones of the Tehuacán-Cuicatlán Valley, central México, let standing trees and shrubs in their agroforestry systems (AFS)

\begin{tabular}{|c|c|c|c|c|}
\hline & Reasons & Temperate zones & Arid zones & Tropical dry and wet zones \\
\hline \multirow[t]{9}{*}{ Utilitarian } & Edible product & $x$ & $x$ & $x$ \\
\hline & Firewood & $x$ & $x$ & $x$ \\
\hline & Fodder & $x$ & $x$ & $x$ \\
\hline & Edible fruit & $x$ & & $x$ \\
\hline & Tools & $x$ & $x$ & $x$ \\
\hline & Medicine & $x$ & $x$ & $x$ \\
\hline & Timber & $x$ & & \\
\hline & Construction & & $x$ & \\
\hline & Beverages & $x$ & $x$ & \\
\hline \multirow[t]{7}{*}{ Ecosystem benefits } & Shade & $x$ & $x$ & $x$ \\
\hline & Maintenance of fertility & $x$ & $x$ & \\
\hline & Erosion control & & $x$ & $x$ \\
\hline & Water control & & & $x$ \\
\hline & Windbreaks & $x$ & & $x$ \\
\hline & Attractor of rain & $x$ & & \\
\hline & Boundary & $x$ & $x$ & \\
\hline \multirow[t]{4}{*}{ Crop management } & Support climbing crops & $x$ & & \\
\hline & Habitat of useful species & & $x$ & $x$ \\
\hline & Storing straw & & $x$ & \\
\hline & Conforming the terrain & & & \\
\hline \multirow[t]{5}{*}{ Ethics } & Part of nature & $x$ & $x$ & \\
\hline & Ornamental & & & $x$ \\
\hline & Ceremonial & & $x$ & $x$ \\
\hline & Does not affect & $x$ & & $x$ \\
\hline & Use regulations & & & $x$ \\
\hline
\end{tabular}


Valley. Kuojtakiloyan are managed by the Náhuatl people, and it is mainly directed to produce coffee under shaded conditions, but people maintain in the systems up to 140 plant species, nearly $96 \%$ of them deliberately maintained because of their use. Together with such a high plant diversity, other associated biodiversity has been reported, mainly birds, amphibians and insects. The Kuojtakiloyan is representative of several similar systems practiced in tropical areas of Mexico by traditional peoples. It may be associated to cocoa, pineapple and other fruit production trees plantations, or other main crops, determining monetary benefits. However, these crops are commonly in association with multiple resources, retaining the capacity of maintaining high biodiversity and ecosystem services.

Several studies have reported that these systems may maintain on average nearly $60 \%$ of species of plants, birds, insects and mammals recorded in the neighbouring forest zones [27]. Consequently, AFS are particularly important in the conservation policies of these areas, which are the reservoirs of the highest biodiversity and indigenous cultures of the whole planet [41]. Paradoxically, the tropical zones are also considered the most strongly disturbed areas on Earth [67, 68]. Approximately $70 \%$ of their plant cover has been converted into agriculture or grassland areas [26], which has determined local extinction of numerous species and threatening tropical biodiversity [69]. The natural habitats are progressively decreasing; for instance, according to FAO [70] in Mexico and Central America the deforestation rate is nearly $1.2 \%$ of the total cover per year, which proportionally increases fragmentation, severe degradation and pressure on the remaining forest [33].

In numerous tropical landscapes, AFS are the managed ecosystems more similar to natural forests [5]. During the last decades, agroforestry has promoted in tropical areas strategies to manage in balanced ways natural resources of forests in association with agriculture, water and soil management, and biodiversity conservation $[9,71]$ together with efforts for the maintenance of ecosystem services [33, 37]. Such holistic approach of ecosystem management has resulted in successful practices for conserving biodiversity, ecosystems and their capacity for recovering after disturbance. Removing trees from AFS may determine the reduction of resistance and resilience of the agricultural system and the household units that manage them, increasing the incidence and vulnerability to pests and climate change $[4,5]$. Therefore, the maintenance of these elements in the systems becomes critical for sustainability of the natural and artificial systems, as well as the households' life.

In the tropics of the world, there are numerous examples of AFS of coffee and cocoa plantations favouring conservation (Table 2), but AFS combining production of staple grain crops combined with fruit trees are also common. These systems have also demonstrated to be relevant in biodiversity conservation, maintaining high levels of species richness, diversity and structure similar to those of cocoa AFS referred to above [63, 72, 73]. Studies by Asase and Tetteh [74] confirm that trees maintained in these systems provide shade, reduce evapotranspiration, erosion and destructive effects of strong wind (Table 2).

A common problem in AFS of the tropical regions is the increasing of mechanization and use of agrochemicals, which has in turn favored increasing of pests problems $[1,67,68]$ (Table 4). The industrialization of agriculture and public policies favoring intensive agricultural systems have been a main cause of transformation from diversified traditional agriculture to agro-industrial systems highly dependent from agrochemical inputs $[9,72,75]$.

\section{AFS in temperate zones}

Temperate zones have demonstrated high potential for favoring long-term sustainable management practices of AFS and natural resources use [20, 76, 77]. In the Tehuacán Valley, we recently documented [49] that AFS associated to temperate forests are mainly managed with the multi-crop traditional system called milpa (commonly cultivating maize, beans and squashes) maintaining 79 species of trees and shrubs, $86 \%$ of them being native species native to the region, representing nearly $43 \%$ of woody flora of the forests surrounding the AFS (Tables 2 and 5). Local people said that the main reasons for maintaining trees and shrubs in their agricultural plots are their use as fruit trees, fuelwood, shade, protection of annual crops against wind, beauty, and respect to nature, among other purposes (Table 1, Fig. 2).

AFS in these areas may be as ancient as in the tropical zones not only in the Tehuacán Valley but also in Mexico. In the temperate zones of the Americas, there are abundant records of old and recent annual crop systems of maize cultivated in combination with native trees including pines, oaks and other wild species, as well as fruit trees such as apples, pears, plums, among others [78]. In these areas there are specific problems such as climatic and microclimatic conditions such as snow, hailstorms, and frosts, maintaining of soil nutrients, control of underground water level, maintenance of favorable habitats for plants, insects and other animal species, fungi and microorganisms, all of them representing challenges for agricultural practices; stabilization of soils protection against wind are among the most common factors motivating maintenance of natural vegetation in AFS of this zones [79] (Table 3). The most common agroforestry practices in temperate zones are the combination of annual crops with fruit and timber producing trees, frequently forming terraces, as well as a 
Table 2 Examples of species richness and diversity maintained in agroforestry systems (AFS) in different tropical, temperate and arid zones of the World

\begin{tabular}{|c|c|c|c|c|c|c|c|}
\hline Reference & Environment & Region & AFS & $\begin{array}{l}\text { Species } \\
\text { richness }\end{array}$ & Diversity & $\begin{array}{l}\% \text { of species } \\
\text { from forest }\end{array}$ & $\begin{array}{l}\text { Taxa } \\
\text { evaluated }\end{array}$ \\
\hline Bhagwat et al. (2008) [27] & Tropical & General review & $\begin{array}{l}\text { General } \\
\text { review }\end{array}$ & N/A & N/A & $60 \%$ & General \\
\hline Toledo and Moguel (2012) [66] & Tropical & Puebla, México & $\begin{array}{l}\text { Coffee } \\
\text { plantations }\end{array}$ & 140 & N/A & & Plants \\
\hline \multirow[t]{3}{*}{ Steffan-Dewenter et al. (2007) [68] } & \multirow[t]{3}{*}{ Tropical } & \multirow{3}{*}{$\begin{array}{l}\text { Central Sulawesi, } \\
\text { Indonesia. }\end{array}$} & \multirow{3}{*}{$\begin{array}{l}\text { Cocoa } \\
\text { plantations }\end{array}$} & 189 trees & & $40 \%$ & Trees \\
\hline & & & & 166 herbs & N/A & & Herbs \\
\hline & & & & 208 insects & & $40 \%$ & Insects \\
\hline \multirow[t]{5}{*}{ Sonwa et al. (2007) [91] } & \multirow[t]{5}{*}{ Tropical } & \multirow{5}{*}{$\begin{array}{l}\text { Central and southern } \\
\text { Cameroon, }\end{array}$} & \multirow{5}{*}{$\begin{array}{l}\text { Cocoa } \\
\text { plantations }\end{array}$} & 203 & Sørensen 0.44 & & Trees \\
\hline & & & & & Shannon 3.7 & & \\
\hline & & & & & Simpson 0.12 & & \\
\hline & & & & & & $70 \%$ & Ants \\
\hline & & & & 30 & N/A & $\mathrm{N} / \mathrm{A}$ & Ants \\
\hline \multirow[t]{2}{*}{ Asase and Tetteh (2010) [74] } & \multirow[t]{2}{*}{ Tropical } & \multirow[t]{2}{*}{ Adjeikrom, Ghana } & $\begin{array}{l}\text { Cocoa } \\
\text { plantations }\end{array}$ & 27 & Shannon 2.46 & N/A & Trees \\
\hline & & & Other crops & 31 & $\begin{array}{l}\text { AFS } 2.6 \text { Forest } \\
4.94\end{array}$ & N/A & \\
\hline Okubo et al. (2010) [63] & Tropical & Java, Indonesia & $\begin{array}{l}\text { Bamboo } \\
\text { gardens }\end{array}$ & 76 & Shannon: 1.66 & N/A & Trees \\
\hline Vallejo et al. (2014) [49] & Temperate & Tehuacán Valley, Mexico & Maize fields & 79 & N/A & $43 \%$ & $\begin{array}{l}\text { Trees and } \\
\text { shrubs }\end{array}$ \\
\hline Moreno-Calles et al. (2010) [15] & Arid & Tehuacán Valley, Mexico & Maize fields & 73 & N/A & $59 \%$ & Plants \\
\hline \multirow[t]{3}{*}{ Nabhan $(1987,2007)[24,54]$} & \multirow[t]{3}{*}{ Arid } & \multirow[t]{3}{*}{ Northern Mexico } & \multirow{3}{*}{$\begin{array}{l}\text { Cultivated } \\
\text { oasis }\end{array}$} & 139 & N/A & $\mathrm{N} / \mathrm{A}$ & Plants \\
\hline & & & & 103 & N/A & N/A & Birds \\
\hline & & & & 14 & N/A & $\mathrm{N} / \mathrm{A}$ & Mammals \\
\hline Blanckaert et al. (2007) [45] & Arid & Tehuacán Valley, México & Maize fields & 161 & N/A & $49 \%$ & Herbs \\
\hline
\end{tabular}

N/A The information was not available in the revised article

great variety of practices for establishing fences for protecting plots against strong winds, soil erosion, and other multiple purposes (Table 3).

The diversity and structure of plant components of AFS in these zones allow to regulate microclimatic conditions, to favor moderate temperatures, reducing intensity of solar radiation and improving the water (decreasing effects of frosts, snow and storms, increasing the humidity and buffering erosion effects of rain and wind, and reducing the loss of evaporation of superficial water). Although trees may compete for water with crops, benefits are higher [76].

\section{Agroforestry practices}

Living fences were identified as the main and most extent agroforestry practice. In these fences people maintain the greater number of individual plants of wild vegetation, and are mainly directed to protect plots against strong wind. Another important practices are vegetation islands, which are arranged in small vegetation patches that allow maintaining natural vegetation which is let standing because of their use and ecosystem services without hindering agricultural labors such as passing through of ploughs or even tractors. In these patches it is common to find domesticated fruit producing trees together with several native species let standing with several purposes. Vegetation patches are mainly left growing in areas of the plots where it is difficult to practice agricultural activities; for instance where stones are abundant, the topography particularly pronounced flooded areas or inappropriate soils. In these areas people commonly use to let standing growth and abundance of a great variety of species of natural vegetation, particularly in areas that do not affect agricultural practices.

Temperate zones generally have high availability of water, enough for allowing production of domesticated trees, and sometimes more than one season of production of annual crops. The main reasons for maintaining vegetation in AFSs of this region are food benefits, but we identified a total of 16 reasons mentioned by people (Table 1 ).

AFS of temperate zones have been documented as important reservoirs of native biodiversity; on average, agroforestry systems harbor two to three times more species than intensive systems [80]. It may also include a high number of species and crop varieties specifically 

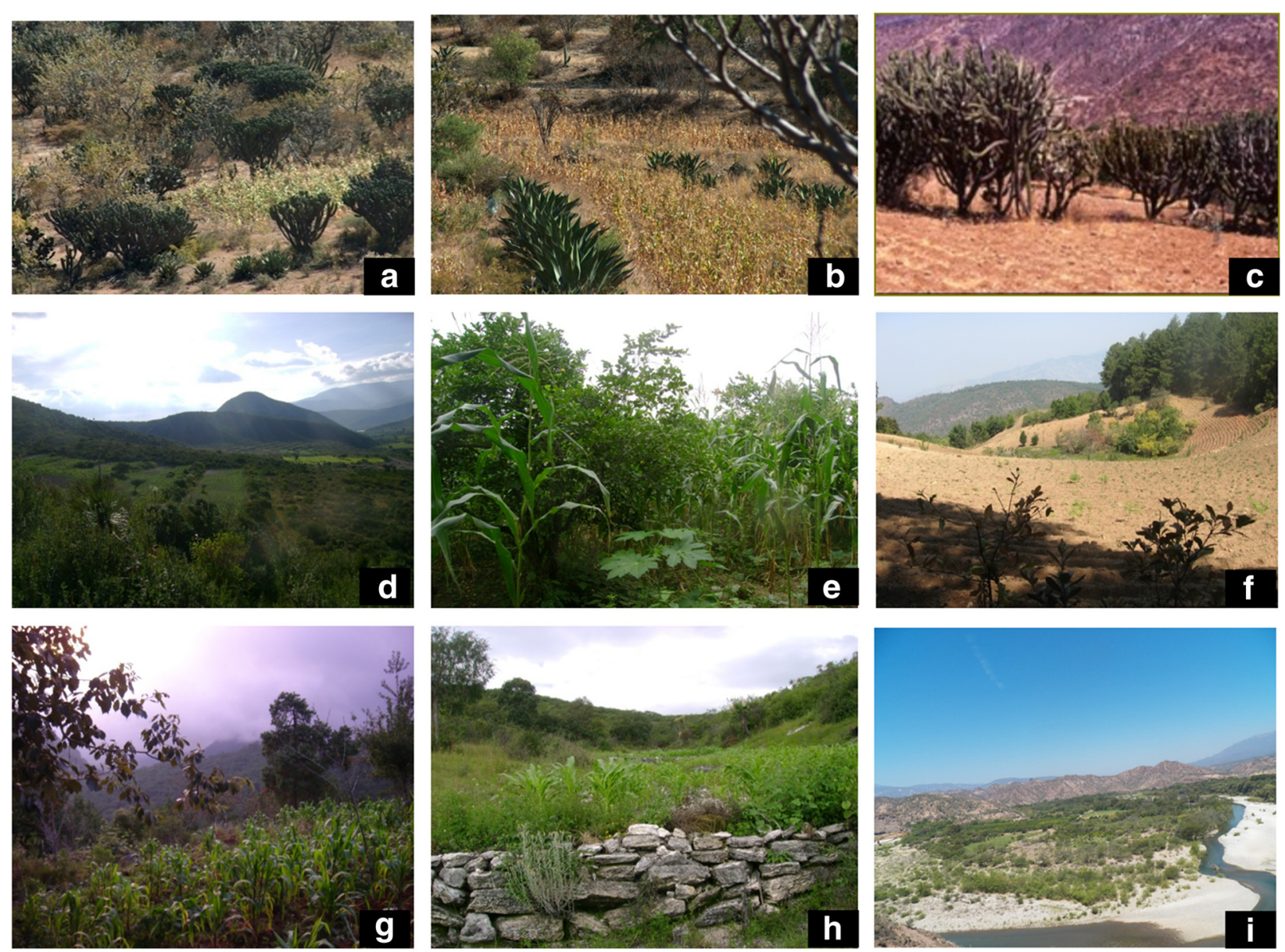

Fig. 2 Mexican ethnoagroforestry systems, integrating elements from forests (wild) and agricultural or domesticated components of biodiversity in the Tehuacan Valley. The image illustrate several agroforestry practices such as friges of vegetation, isolated trees, terraces, and barriers against strong wind. AFS of the Tehuacán Valley showed in this image represent different environments discussed in the text but cultivation of maize and beans are the main annual crops in all cases, changing the composition of the wild vegetation composing the system. a AFS with Polakia chichipe and Myrtllocactus schenckii in the arid zone studied, $\mathbf{b}$ Fringes of vegetation mainly composed with Agave salmiana in the arid zone studied, c AFS with patches of vegetation composed by Escontria chitilla, Myrtillocactus schenckii, Polaskia chchipe and P. chende in the arid zone studied; $\mathbf{d}$ Fringes of terraces in the sub-humid region studied; e combination of native and domesticated trees, crops and herbaceous species; $\mathbf{f}$ Example of the aspect of an Island of vegetation in a cleared cropland; $\mathbf{g}$ Terraces constructed with ground and plants, $\mathbf{h}$ Terraces with stones, i General aspect of the landscape of AFS associated to the river

adapted. For instance, nearly 10,000 varieties of apples and 1000 to 2000 varieties of plums are maintained in situ in these systems [81].

In areas of AFS of temperate zones the heterogeneity of landscapes has being decreasing with agroindustrialization, a phenomenon that is more pronounced in developed countries, but even in those zones AFS have adapted to changes, maintaining and providing ecological structure for species inhabiting the agricultural landscapes [82] (Table 4). These landscapes provide essential services for human wellbeing $[76,81]$.

\section{AFS of arid zones}

Arid zones are characteristic for low rainfall, high radiation and extreme temperatures. These conditions determine high hydric stress and biotic communities of these areas have particular adaptations, highly specialized to survive in such extreme conditions [83]. Ecosystems of these zones are particularly fragile, and relatively small disturbances may determine great consequences including the irreversible loss of components [69], such loss may be more drastic than in other ecosystems [83-86]. Production activities have required fine and deep ecological knowledge and management practices according to particular ecological, cultural, and social components [86]. In order to minimize the negative effects associated to environmental conditions, local peoples of the arid lands have developed production systems in which the woody perennial species have an important role in terms of production and conservation [87]. 
Table 3 Ecosystem benefits reported for agroforestry systems from tropical, temperate and arid zones

\begin{tabular}{|c|c|c|c|c|}
\hline Reference & Environment & Region & SAF & Ecosystem benefits \\
\hline DeClerck et al. (2010) [33] & Tropical & Mesoamerica & General review & $\begin{array}{l}\text { Biological corridors enhance secondary succession, favour } \\
\text { pollination, biological control of pests, maintenance of } \\
\text { microclimates, favour restoration. }\end{array}$ \\
\hline Tscharntke et al. (2011) [5] & Tropical & $\begin{array}{l}\text { Tropical areas } \\
\text { of the World }\end{array}$ & $\begin{array}{l}\text { Cocoa and } \\
\text { coffee } \\
\text { plantations }\end{array}$ & $\begin{array}{l}\text { Provide biomass for construction, fuel and food (fruit). Favour } \\
\text { soil fertility stimulating decomposition of leaf litter, the nutrient } \\
\text { cycles and erosion control. Increasing carbon sequestration and } \\
\text { reduction of GEG emitions, contributing to mitigation of effects } \\
\text { of climate change. Improve functional biodiversity. }\end{array}$ \\
\hline Bhagwat et al. (2008) [27] & Tropical & $\begin{array}{l}\text { Tropical areas } \\
\text { of the World }\end{array}$ & General review & $\begin{array}{l}\text { Refuge of species out of protected areas, maintain heterogeneity } \\
\text { of habitat and landscape, reduce anthropogenic pressure on wild } \\
\text { areas, may be buffer or corridor areas among conserved zones. }\end{array}$ \\
\hline $\begin{array}{l}\text { Steffan-Dewenter et al. (2007) } \\
\text { [68] }\end{array}$ & Tropical & $\begin{array}{l}\text { Central } \\
\text { Sulawesi, } \\
\text { Indonesia. }\end{array}$ & $\begin{array}{l}\text { Cocoa } \\
\text { plantations }\end{array}$ & $\begin{array}{l}\text { Reduce soil temperature, increase humidity and decomposition } \\
\text { rate and maintain soil fertility. }\end{array}$ \\
\hline Jose et al. (2004) [79] & Temperate & General review & General review & $\begin{array}{l}\text { Biological control through ecological interactions among species, } \\
\text { nitrogen fixation due to presence of legume species. }\end{array}$ \\
\hline Quinkenstein et al. (2009) [76] & Temperate & Europa & General review & $\begin{array}{l}\text { Improve microclimates and thus the stability of productivity of } \\
\text { crops. Efficient use of hydric resources and nutrients, sustainable } \\
\text { use with low input of fertilizers, pesticides and hand labour. } \\
\text { Increase structural heterogeneity of landscape. Promotion of } \\
\text { biodiversity, favoring landscape connection. Carbon capture } \\
\text { in soil. }\end{array}$ \\
\hline Vallejo et al. (2014) [49] & Temperate & $\begin{array}{l}\text { Tehuacán Valle, } \\
\text { México }\end{array}$ & Maize fields & $\begin{array}{l}\text { Provide shade, protect against strong winds, and provide fruit. } \\
\text { Fuel wood and fodder. }\end{array}$ \\
\hline $\begin{array}{l}\text { Shankarnarayan, K. A., Harsh, L. } \\
\text { N., \& Kathju }\end{array}$ & Arid & India & Prosopis AFS & $\begin{array}{l}\text { Stabilize dunes, maintain trees adapted to thin soils, reduce } \\
\text { effects of strong wind, reduce evapotranspiration, multipurpose } \\
\text { trees (fruit, fuel, fodder, etc.). }\end{array}$ \\
\hline Moreno-Calles et al. (2010) [15] & Arid & $\begin{array}{l}\text { Tehuacán } \\
\text { Valley, México }\end{array}$ & Maize fields & Provide shade, fodder and fruit \\
\hline Altieri and Toledo (2005) [22] & Arid & México & General review & $\begin{array}{l}\text { Conservation of soil and water, reduce evapotranspiration, } \\
\text { maintain soil fertility and useful species. }\end{array}$ \\
\hline
\end{tabular}

Table 4 General advantages and problems of agroforestry systems of tropical, temperate and arid zones

\begin{tabular}{|c|c|c|c|c|}
\hline Ecological zone & Uses & Main agroforestry practices & Ecosystem benefits & Problems \\
\hline \multirow[t]{4}{*}{ Tropical } & - Shade crops (coffee. cocoa) & Fringes & Soil protection & Intensification \\
\hline & - Fruit production & Living fences & Shade & \\
\hline & - Timber products & Isolated trees & Soil fertility & LOSS of TEK \\
\hline & - Pest control & & High biodiversity & Pesticides, deforestation \\
\hline \multirow[t]{5}{*}{ Temperate } & - Windbreaker & Windbreaker barriers & Microclimate conditions & Intensification \\
\hline & -Snowing damage & Living fences & Buffering winds & No replacement of trees \\
\hline & - Fruit production & Fringes, isolated trees & Soil protection & Fruit commercialization \\
\hline & - Timber products & Vegetation patches & Reduction of damages by frosts & LOSS of TEK \\
\hline & - Control of pests & Vegetation patches & Biodiversity & Industrialization \\
\hline \multirow[t]{4}{*}{ Arid } & - Resistance to dryness & Windbreaker barriers & Water management & Specificity of native species \\
\hline & - Retention of humidity and soil & Isolated trees & Soil protection & Abundance of rare species \\
\hline & - Timber and non-timber & Vegetation patches & Shade & Intensification \\
\hline & • Medicinal & Living fences, fringes & Biodiversity & । \\
\hline
\end{tabular}


Several studies illustrate the capacity of AFS of arid zones for conserving biological diversity. In the Tehuacán Valley, AFS are managed at small scale, mainly associated to the multi-crop called milpa, with low use of chemical inputs and mechanization, and most commonly their products destined to direct consumption by households [47]. Several studies conducted in the area (Table 4), reveal that AFS play an important role to satisfy human needs and conserving biodiversity in terms of species richness and genetic diversity of particular species [88-90]. Moreno-Calles et al. [15, 47] reported that on average $59 \%$ of plant species of natural forests are maintained in AFS, and that some endemic species such as Escontria chiotilla and Lemaireocereus hollianus may increase their abundance in these systems. Blanckaert et al. [45] found nearly 161 of herbaceous plant species in agricultural systems of the area, nearly $49 \%$ of them being present in the local forests (Tables 1, 2 and 5). Dominant arborescent cacti species of the region such as Stenocereus stellatus, S. pruinosus, Escontria chiotilla, Polaskia chende and $P$. chichipe have been reported in AFS to have on average $93.8 \%$ of genetic variation occurring in wild populations. But in some plots were recorded with even higher levels of genetic diversity than in wild populations $[12,15,88]$. It is relevant in addition to mention that populations of the species mentioned in AFS maintain a dynamic gene flow with wild populations, which also indicate that AFS are key areas for implementing policies of regional biodiversity conservation.

\section{Agroforestry practices}

In the AFS of the arid zones of the TCV, we documented several managemet practices, such as vegetation islands and patches, living fences and isolated trees. The latter agroforestry practice is represenred bt arboreaus species of great economic and cultural value for local people. These include big trees providing shade, fruits, fuelwood and fodder. In arid zones of the TCV the main reason to

Table 5 General socio-ecological and technological aspects recorded in AFS in different indigenous and Mestizo communities of the Thuacán Valley, México

\begin{tabular}{|c|c|c|c|c|c|c|c|c|}
\hline \multirow[b]{2}{*}{ Aspect } & \multirow[b]{2}{*}{ Variable } & \multicolumn{3}{|l|}{ Temperate } & \multirow{2}{*}{$\begin{array}{l}\text { Arid } \\
\text { San Luis Atolotitlán }\end{array}$} & \multicolumn{3}{|c|}{ Arid-alluvial valleys } \\
\hline & & $\begin{array}{l}\text { Santa María } \\
\text { Coyomeapan }\end{array}$ & $\begin{array}{l}\text { San } \\
\text { Lorenzo } \\
\text { Pápalo }\end{array}$ & $\begin{array}{l}\text { Santa María } \\
\text { Ixcatlán }\end{array}$ & & $\begin{array}{l}\text { Santiago } \\
\text { Quiotepec }\end{array}$ & $\begin{array}{l}\text { Zapotitlán } \\
\text { Salinas }\end{array}$ & $\begin{array}{l}\text { San Losé } \\
\text { Axusco }\end{array}$ \\
\hline \multirow[t]{2}{*}{ Sociocultural } & Ethnicity & Náhuatl & Cuicateco & Ixcateco & Mestizo and Náhuatl & $\begin{array}{l}\text { Mestizo and } \\
\text { Cuicateco }\end{array}$ & $\begin{array}{l}\text { Meztizo and } \\
\text { Mixteco }\end{array}$ & Náhuatl \\
\hline & Land tenure & $\begin{array}{l}\text { Private, ejidal } \\
\text { and } \\
\text { communal }\end{array}$ & $\begin{array}{l}\text { Communal } \\
\text { and private }\end{array}$ & Communal & Ejidal & $\begin{array}{l}\text { Communal } \\
\text { and private }\end{array}$ & Communal & $\begin{array}{l}\text { Communal } \\
\text { and ejidal }\end{array}$ \\
\hline \multirow[t]{6}{*}{$\begin{array}{l}\text { Farming } \\
\text { practices }\end{array}$} & Crops & $\begin{array}{l}\text { Corn, beans, } \\
\text { squashes, } \\
\text { pumpkins, } \\
\text { peas }\end{array}$ & $\begin{array}{l}\text { Corn, bean, } \\
\text { gourd, fava } \\
\text { beans, peas }\end{array}$ & $\begin{array}{l}\text { Corn, } \\
\text { beans and } \\
\text { squashes }\end{array}$ & $\begin{array}{l}\text { Corn, beans and } \\
\text { squashes }\end{array}$ & $\begin{array}{l}\text { Corn, beans } \\
\text { and squashes }\end{array}$ & $\begin{array}{l}\text { Corn, beans } \\
\text { and squashes }\end{array}$ & $\begin{array}{l}\text { Corn, beans } \\
\text { and squashes }\end{array}$ \\
\hline & Fallow & 1 year & $1-3$ years & 6 months & $1-5$ years & 6 months & 6 months & 6 months \\
\hline & Irrigation & No & No & No & No & Yes & Yes & Yes \\
\hline & Machinery & Mattock & $\begin{array}{l}\text { Plough and } \\
\text { mattock }\end{array}$ & $\begin{array}{l}\text { Tractor and } \\
\text { mattock }\end{array}$ & Plough & Plough & $\begin{array}{l}\text { Tractor and } \\
\text { mattock }\end{array}$ & $\begin{array}{l}\text { Tractor and } \\
\text { Plough }\end{array}$ \\
\hline & Agrochemicals & No & Yes & No & No & Yes & Yes & No \\
\hline & Livestock & Yes & Yes & Yes & Yes & Yes & $\mathrm{No}$ & Yes \\
\hline \multirow[t]{2}{*}{$\begin{array}{l}\text { Agroforestry } \\
\text { systems }\end{array}$} & $\begin{array}{l}\text { Agroforestry } \\
\text { practice }\end{array}$ & $\begin{array}{l}\text { Boundaries, } \\
\text { windbreaks } \\
\text { and isolated } \\
\text { trees }\end{array}$ & $\begin{array}{l}\text { Boundaries } \\
\text { and } \\
\text { vegetation } \\
\text { islands }\end{array}$ & $\begin{array}{l}\text { Boundaries } \\
\text { and } \\
\text { patches of } \\
\text { vegetation }\end{array}$ & $\begin{array}{l}\text { Isolated trees, } \\
\text { vegetation islands and } \\
\text { fringes against soil } \\
\text { erosion, vegetation } \\
\text { surrounding the fields. }\end{array}$ & $\begin{array}{l}\text { Fringes for } \\
\text { water } \\
\text { managenment } \\
\text { and against } \\
\text { soil erosion }\end{array}$ & $\begin{array}{l}\text { Fringes for } \\
\text { water } \\
\text { managenment } \\
\text { and against } \\
\text { soil erosion }\end{array}$ & $\begin{array}{l}\text { Fringes for } \\
\text { water } \\
\text { managenment } \\
\text { and against } \\
\text { soil erosion }\end{array}$ \\
\hline & Principal uses & $\begin{array}{l}\text { Edible fruit, } \\
\text { Other edible } \\
\text { product and } \\
\text { Firewood }\end{array}$ & $\begin{array}{l}\text { Shade, } \\
\text { firewood } \\
\text { and } \\
\text { boundary }\end{array}$ & $\begin{array}{l}\text { Shade, } \\
\text { firewood } \\
\text { and } \\
\text { boundary }\end{array}$ & $\begin{array}{l}\text { Edible fruit, firewood } \\
\text { and shade }\end{array}$ & $\begin{array}{l}\text { Edible fruit, } \\
\text { shade and } \\
\text { fodder }\end{array}$ & $\begin{array}{l}\text { Asthetic } \\
\text { (beauty), shade } \\
\text { and } \\
\text { Maintaining } \\
\text { water }\end{array}$ & $\begin{array}{l}\text { Other edible } \\
\text { product, shade } \\
\text { and fodder }\end{array}$ \\
\hline \multirow[t]{2}{*}{ Ecological } & $\begin{array}{l}\text { Species } \\
\text { richness }\end{array}$ & 39 & 18 & 29 & 71 & 32 & 58 & 10 \\
\hline & $\begin{array}{l}\text { Diversity } \\
\text { (Shannon } \\
\text { Índex) }\end{array}$ & 3 & 2.5 & 2 & 3.2 & $\mathrm{~N} / \mathrm{A}$ & $\mathrm{N} / \mathrm{A}$ & $\mathrm{N} / \mathrm{A}$ \\
\hline
\end{tabular}


maintain native vegetation in agricultural plots are shade, fodder, and other 13 reasons (Table 1).

In other regions of Mexico, in the Sonoran Desert for instance, Nabhan [54] documented the traditional agricultural techniques practiced by the Papago people, who have conserved the oases of their territories and have developed a complex system of biotic interactions. This author identified eight plant associations and various agroforestry practices including living fences and windbreaker barriers, as well as high levels of diversity of trees, birds and mammals. The Papago have modified the landscape geomorphology through terraces, channels and flood zones [22, 91]. In the Mezquital Valley in central Mexico, the Ñañhú or Otomí people have constructed terraces and borders to manage water and sediments to improve soil and humidity for crops. Particularly important for these purposes are agave, which in addition provide multiple products used as food, beverages, and fibers, and others [22] (Table 3).

In the arid zones of the numerous human cultures have interacted with the difficult conditions of these zones for thousands of years, and a significant amount of knowledge and techniques have been developed [22, 24], which are all crucial at present for designing the future. Investigating trees and shrubs associated to crops may provide valuable information for improving the AFS, conserving biodiversity and supporting techniques for restoring disturbed areas of arid zones [24, 47] (Tables 3 and 4, Fig. 2).

\section{Discussion}

\section{TEK and biodiversity and ecosystem management}

Our studies in the Tehuacán Valley reveal that the bases of variation of practices and management techniques at both particular elements of biodiversity and ecosystem levels is the presence, explicit expression and depth of traditional ecological knowledge. In that region, we have documented more than nearly 2000 species of plants that are used with a high variety of purposes. Local people know their useful properties but also details about their distribution, abundance, interactions with other plants and animals and they have an extraordinary information about germination, growth and phenology. All these elements are crucial expressions of TEK that significantly influence their decisions about what and how managing in AFS. Blancas et al. [46] documented with an extraordinary detail how people make decisions about which edible plants may or may not be managed, should or should not be managed, and how and in which systems would be managed. These authors show that TEK is an on-going construction, continually adapting to the changing conditions. The new conditions, as the authors discuss, may be ecologically, economically, culturally and technically influenced. And all these elements may be highly dynamic.
Our studies in the Tehuacán Valley (Table 5) allow seeing that indigenous peoples may adopt technologies of intensive agriculture, and they decide how necessary and viable their adoption is. Ethnicity may or may not be representative of the maintenance of traditional agricultural practices or the adoption of modern technologies. For instance, Table 5 shows that in Axuxco, an eminently Náhuatl village, people decided the adoption of modern elements of agriculture (tractor and agrochemicals), whereas in Santa María Ixcatlán, where the Ixcatec people are markedly few and Mestizo people is the great majority, the traditional agricultural practices in AFS are clearer. Another important aspect to mention is that adoption of modern agricultural techniques not necessarily is the cause of decreasing vegetation cover and biological richness and diversity maintained in AFS. For instance, in Table 5 it can be seen that some communities using tractor and agrochemicals may also maintain a high vegetation cover and plant diversity inside their plots. Therefore, causes and effects of traditional management and intensive agriculture are not linear in relation to ethnicity and vegetation cover, respectively. These are aspects that deserve a deeper analysis, which is of great importance for constructing policies in relation to agricultural patterns and biodiversity conservation.

Literature available on this and other issues reviewed in this analysis has been produced from different approaches and an appropriate comparison and establishing of general conclusions is for the moment difficult. However, further research on AFS including explicitly the questions of how traditional societies adopt and adapt modern agricultural elements and how much these elements influence decreasing biodiversity conservation capacity of AFS are of high importance for constructing alternatives and policies at different scales.

\section{Particularities of AFS in specific environmental contexts}

Local peoples manage AFS according to environmental particularities in order to make them functional, productive and viable. In tropical zones, AFS multi-crops are commonly associated to let standing or planted components of the exceptionally diverse natural forests. Coffee and cocoa plantations are out-standing AFS in terms of biodiversity conservation. Soil degradation due to rain and deforestation are main problems faced by people through conserving high species richness, mainly of fruit and fine timber trees but also numerous herbaceous plants. In temperate zones, the main challenges are erosion caused by rain and wind, as well as loss of production caused by frosts, snow, storms and wind. In these areas, the windbreaker barriers, terraces and borders, as well as isolated trees contribute to create propitious microenvironments in AFS, particularly through trees 
providing fruit, fuel and wood. In the arid zones, the environmental pressures are mainly associated to drought and erosion caused by wind and the infrequent but heavy rains. These zones are particularly fragile since removal of particular species may determine drastic alterations in biotic interactions (pollination, seed dispersal, and facilitation of establishment of numerous plant species by nurse plant species), which may be particularly sensible because native species of perennial plants generally have slow growth rates. AFS in these areas are designed and managed in order to attend these problems and to optimize and ensure availability of valuable natural resources, as well as procuring ecosystem benefits associated to humidity, shade, propitious microenvironments and soil conservation (Tables 3 and 4).

\section{How does capacity of biodiversity conservation changes with environmental contexts?}

The highest species richness of AFS have been reported in tropical areas, which is consequence of the also high natural species richness recorded of these ecosystems; however, when considering the proportion of species maintained in AFS, the ciphers are similar in the three environmental zones analyzed (Table 2). This result suggests that biodiversity conservation capacity is not an exclusive function of the nature of ecosystems.

The diversity of strategies for practicing AFS is high, and these patterns are associated to the diversity of agricultural techniques developed among ecological zones as well as regions of the World. It is difficult with the information available for the moment establish general conclusions. Every region has environmental socio-ecological and biocultural particularities, and all of them influence the responses and strategies practiced by human groups. AFS are ancient systems of agricultural production and most probably the earliest forms of agriculture. Therefore, the experiences accumulated during thousands of years have influenced the diversity of technical responses.

Today, inventorying the diversity of strategies is particularly important to enhance the option of AFS as alternative of raw matter production for food and other industries based on more environmental friendly principles. Intensive agriculture has been highly criticized since it has required high amounts of water, machines, oil-based energy and toxic agrochemicals. Agricultural production based on organisms genetically modified has demonstrated not to be a viable solution to the environmental problems initiated during the green revolution but, contrarily, the possible cause of even higher socio-ecological problems. Therefore, the construction of alternatives should be based on the valuable millenary experiences of humans throughout the world that have been able to conceal conservation of biodiversity and ecosystems with the satisfaction of raw matter required for diverse industries.
Some few companies producing seeds and agrochemicals are the main beneficiaries of the intensive technological alterative production models, but not most of the agricultural producers of the World, who, for the contrary are in risk of make stronger their dependent relations with such companies and making even deeper de poverty and inequity prevailing at planetary scale. This fact should motivate reflexions of humans to other models of future perspectives, based more strongly on the traditional ecological knowledge and management techniques, which have sustained the humanity for nearly $99 \%$ of the history of humans as agriculturalists. Consequently, intensification of studies of strategies and techniques of AFS throughout the World should be a priority of research for several scientific disciplines, outstandingly ecology, agroecology and ethnobiology.

\section{Conclusions}

AFS have been used since the origins of agriculture, and have maintained a millenary richness and ecosystem functions that are agroecological lessons for rescuing and constructing technological innovation for sustainable agricultural management and landscape maintenance and recovering. AFS summarize crucial biocultural heritage. AFS have important advantages for conserving biodiversity and ecosystem functions while satisfying human needs, at different spatial scales.

Technical experiences varied extraordinarily in part associated to the characteristics of the ecosystems where agriculture is conducted, but also according to human culture and history in the regions of the world. A global research strategy directed to analyse agricultural techniques, soils, productivity, and resilience capacity of the systems, biodiversity conservation challenges, among other main topics in different ecological and cultural contexts is a priority. The construction of alternatives technically and culturally viable would be possible based on such research strategy.

Contribution of such a research strategy would be a valuable source of alternatives more environmentally friendly than intensive agriculture. Each region of the world has a high variety of ecological and cultural conditions and human experience has also been highly variable. Therefore, efforts of such a global strategy require the participation of different disciplines. However, the role of ecology, agroecology and ethnobiology are crucial. Traditional ecological knowledge associated to agroforestry systems synthesize thousands of years of experience of managing biodiversity and agroecosystems, and this knowledge is a key stone for shortening times of building viable alternatives.

The results systematized in this study may not be representative of the situations throughout the world. Such analysis requires systematizing the broad experiences 
and knowledge documented, which is undoubtedly a priority task for ethnobiological and agroecological sciences. Documenting the techniques and purposes for maintaining wild plants together with crops, the richness and diversity biological components of the systems resulting of such intentions, the economic advantage of those actions and their ecological benefits are crucial aspects for designing sustainable strategies of management of these systems.

\section{Abbreviations}

AFS, Agroforestry systems; FAO, Food and Agriculture Organization; TCV, Tehuacán-Cuicatlán Valley; TEK, Traditional ecological knowledge

\section{Acknowledgements}

The authors thank the Posgrado en Ciencias Biológicas of the National Autonomous University of Mexico (UNAM) and the National Council of Science and Technology (CONACYT), Mexico for supporting postgraduate studies and a grant for the first author, respectively. We also thank financial support from CONACYT (Research Project CB-2013-01-221800), and the DGAPA-PAPIIT, UNAM (Research projects IN209214 and IA203115 "Manejo etnoagroforestal de la biodiversidad en México: Aprovechamiento y conservación"), as well as Edgar Pérez-Negrón and Selene Rangel-Landa for fieldwork assistance. We emphatically thank people of the villages of the Tehuacán Valley for sharing their knowledge and experience, their hospitality and friendship.

\section{Funding}

The Posgrado en Ciencias Biológicas of the National Autonomous University of Mexico (UNAM) and the National Council of Science and Technology (CONACYT), Mexico supported postgraduate studies and a grant for the first author. Our studies were financially supported by CONACYT (Research Project CB-2013-01-221800), and the DGAPA-PAPIIT, UNAM (Research projects IN209214 and IA203115.

\section{Authors' contributions}

MV main author of planning the research, fieldwork, interviews, data analysis and writing of this paper. AC main coordinator and advisor of the research project, together with the first author designed the research and data analysis and assisted in writing the paper. AIMC collaborated in the design of the research and coordinated the systematization of information on AFS of Mexico. All authors read and approved the final manuscript.

\section{Authors' information}

MV postdoctoral researcher at the Centro de Investigaciones en Geografía Ambiental (CIGA), UNAM. AC full-time researcher at the Instituto de Investigaciones en Ecosistemas y Sustentabilidad (IIES), UNAM. AIMC researcher at the Escuela Nacional de Estudios Superiores (ENES), UNAM.

\section{Competing interests}

The authors declare that they have no competing interests.

\section{Consent for publication}

People interviewed were informed about the study and eventual publication of the general information, maintaining anonymous source of data.

\section{Ethics approval and consent to participate}

The authors asked permit for carrying out the study to local authorities and people interviewed.

\section{Author details}

${ }^{1}$ Centro de Investigaciones en Geografía Ambiental, Universidad Nacional Autónoma de México (UNAM), Apartado Postal 27-3 (Santa María Guido), Morelia, Michoacán 58190, Mexico. ${ }^{2}$ Escuela Nacional de Estudios Superiores Unidad Morelia, Universidad Nacional Autónoma de México (UNAM), Apartado Postal 27-3 (Santa María Guido), Morelia, Michoacán 58190, Mexico. ${ }^{3}$ Instituto de Investigaciones en Ecosistemas y Sustentabilidad, UNAM, Universidad Nacional Autónoma de México (UNAM), Antigua Carretera a Pátzcuaro 8701, Morelia, Michoacán 58190, Mexico.
Received: 12 January 2016 Accepted: 13 July 2016

Published online: 22 July 2016

\section{References}

1. Donald PF. Biodiversity impacts of some agricultural commodity production systems. Conserv Biol. 2004;18:17-37.

2. Schroth GG, da Fonseca AB, Harvey CA, Gascon C, Vasconcelos HL, Izac AMN. Agroforestry and biodiversity conservation in tropical landscapes. USA: Island Press: 2004

3. Foley JA, DeFries R, Asner GP, Barford C, Bonan G, Carpenter SR, Chapin FS, Coe MT, Daily GC, Gibbs HK, Helkowski JH, Holloway T, Howard EA, Kucharik CJ, Monfreda C, Patz JA, Prentice IC, Ramankutty N, Snyder PK. Global consequences of land use. Science. 2005;309: $570-4$.

4. Tscharntke T, Klein AM, Kruess A, Steffan-Dewenter I, Thies C. Landscape perspectives on agricultural intensification and biodiversity -ecosystem services management. Ecol Lett. 2005;8:857-74.

5. Tscharntke T, Clough Y, Bhagwat SA, Buchori D, Faust H, Hertel D, Hölscher D, Juhrbandt J, Kessler M, Perfecto I, Scherber C, Schroth G, Veldkamp E, Wanger TC. Multi-functional shade-tree management in tropical agroforestry landscapes - a review. J Appl Ecol. 2011;48:619-29.

6. Gibbs HK, Ruesch AS, Achardc F, Claytond MK, Holmgrene P, Ramankuttyf N, Foley JA. Tropical forests were the primary sources of new agricultural land in the 1980s and 1990s. Proc Natl Acad Sci U S A. 2010;107(38): 16732-7.

7. Schmitt CB, Burgess ND, Coad L, Belokurov A, Besançon C, Boisrobert L, Campbell A, Fish L, Gliddon D, Humphries K, Kapos V, Loucks C, Lysenko I, Miles L, Mills C, Minnemeyer S, Pistorius T, Ravilious C, Steininger M, Winkel G. Global analysis of the protection status of the world's forests. Biol Conserv. 2009:142:2122-30.

8. DeFries R, Hansen A, Newton AC, Hansen MC. Increasing isolation of protected areas in tropical forests over the past twenty years. Ecol Appl. 2005:15:19-26.

9. Harvey CA, Komar O, Robin C, Ferguson BG, Finegan B, Griffith DM, Martínez-Ramos M, Morales H, Nigh R, Soto-Pinto L, Van Breugel M, Wishnie M. Integrating Agricultural Landscapes with Biodiversity Conservation in the Mesomerican hotspot. Conserv Biol. 2008;22:8-15.

10. Wallace GN, Barborak J, MacFarland CG. Land-use planning and regulation in and around protected areas: a study of best practices and capacity building needs in Mexico and Central America. Natureza y Conservacao. 2005:3:147-67.

11. Vandermeer J, Perfecto I. The agricultural matrix and the future paradigm for conservation. Conserv Biol. 2007:21:274-7.

12. Perfecto I, Vandermeer J. The agricultural matrix as alternative to the landsparing/ agriculture intensification model. Proc Natl Acad Sci U S A. 2010:107(13):5786-91.

13. Altieri MA. How best can we use biodiversity in agroecosystems. Outlook Agr. 1991;20:15-23.

14. Casas A, Otero-Arnaiz A, Peréz-Negrón E, Valiente-Banuet A. In situ management and Domestication of Plants in Mesoamerica. Ann Bot. 2007; 100:1101-15.

15. Moreno-Calles A, Casas A, Blancas J, Torres I, Rangel-Landa S, Pérez-Negrón E, Caballero J, Masera O, García-Barrios L. Agroforestry systems and biodiversity conservation in arid zones: the case of the Tehuacán-Cuicatlán Valley, Central México. Agrofor Syst. 2010;80:315-31.

16. Blancas J, Casas A, Rangel-Landa S, Moreno-Calles A, Torres I, Pérez-Negrón E, Solís L, Delgado-Lemus A, Parra F, Arellanes Y, Caballero J, Cortés L, Lira R, Dávila P. Plant Management in the Tehuacán-Cuicatlán Valley, Mexico. Econ Bot. 2010;64:287-302.

17. Krishnamurthy L, Ávila M. Agroforestería básica. Programa de las Naciones Unidas para el Medio Ambiente. Serie Textos Básicos para la Formación Ambiental N 3. México D.F., México. 1999.

18. ICRAF. Paths to prosperity through agroforestry. ICRAF's corporate strategy, 2001-2010. Nairobi: International Centre for Research in Agroforestry; 2000.

19. Combe J, Budowski G. Classification of agro-forestry techniques. In: De Las Salas $\mathrm{G}$, editor. Proc agro-forestry systems in Latin America. Costa Rica: CATIE; 1979. p. 17-47.

20. Gordon AG, Newman S. Temperate Agroforestry Systems. UK: Cabi Internacional; 1998. 
21. Casas A, Caballero J, Mapes C, Zárate S. Manejo de la vegetación, domesticación de plantas y origen de la agricultura en Mesoamérica. Bol Soc Bot Mex. 1997;61:31-47.

22. Altieri M, Toledo VM. Natural resources management among small-scale farmers in semi-arid lands: Building on traditional knowledge and agroecology. Ann Arid Zones. 2005;44:365-85.

23. McNeely JA, Schroth G. Agroforestry and biodiversity conservationtraditional practices, present dynamics, and lessons for the future. Biodivers Conserv. 2006;15(2):549-54

24. Nabhan GP. Agrobiodiversity change in a Saharan desert oasis, 1919-2006: historic shifts in Tasiwit (Berber) and Bedouin crop inventories of Siwa, Egypt. Econ Bot. 2007;61:31-43

25. Moreno-Calles Al, Toledo VM, Casas A. Los sistemas agroforestales tradicionales de México: una aproximación biocultural. Bot Sci. 2013;91(4):375-98.

26. Perfecto I, Vandermeer J. Biodiversity conservation in tropical agroecosystems. Ann N Y Acad Sci. 2008;1134;173-200.

27. Bhagwat SA, Willis KJ, Birks HJB, Whittaker RJ. Agroforestry: a refuge for tropical biodiversity? Trends Ecol Evol. 2008;23:261-7.

28. Boffa JM. Parques agroforestales en África occidental: claves para la conservación y la sostenibilidad. Unasylva. 2000;51:11-7.

29. Backes MM. The role of indigenous trees for the conservation of biocultural diversity in traditional agroforestry land use systems: the Bungoma case study: in-situ conservation of indigenous tree species. Agrofor Syst. 2001;52(2):119-32.

30. Sinclair FL. A general classification of agroforestry practice. Agrofor Syst. 1999:46:161-80

31. Vandermeer J, van Noordwijk M, Anderson J, Ong C, Perfecto I. Global change and multi-species agroecosystems: concepts and issues. Agri Ecosyst Environ. 1998;67(1):1-22.

32. Holt-Giménez E. Measuring farmers' agroecological resistance after Hurricane Mitch in Nicaragua: a case study in participatory, sustainable land management impact monitoring. Agri Ecosyst Environ. 2002;93(1):87-105.

33. DeClerck FAJ, Chazdon RL, Holl KD, Milder JC, Finegan B, Martinez- Salinas A, Imbach P, Canet L, Zayra R. Biodiversity conservation in human-modified landscapes of Mesoamerica: Past, present, and future. Special Issue: Biodivers Conserv. 2010;143:2301-13.

34. Eakin H, Benessaiah K, Barrera JF, Cruz-Bello GM, Morales H. Livelihoods and landscapes at the threshold of change: disaster and resilience in a Chiapas coffee community. Reg Environ Change. 2012;12(3):475-88.

35. Daily GC. Nature's services: societal dependence on natural ecosystems. Washington, D.C: Island Press; 1997.

36. Soto-Pinto L, Perfecto I, Caballero-Nieto J. Shade over coffee: its effects on berry borer, leaf rust and spontaneous herbs in Chiapas, Mexico. Agrofor Sys. 2002:55:37-45.

37. Jose S. Agroforestry for ecosystem services and environmental benefits: an overview. Agrofor Syst. 2009;76:1-10.

38. Nair PKR. Agroforestry Systems and Environmental Quality: Introduction. J Environ Qual. 2011:40:784-90.

39. Otero-Arnaiz A, Casas A, Hamrick JL, Cruse-Sanders J. Genetic variation and evolution of Polaskia chichipe (Cactaceae) under domestication in the Tehuacán Valley, central Mexico. Mol Ecol. 2005;14(6):1603-11.

40. Prasad K. Linking trees on farms with biodiversity conservation in subsistence farming systems in Nepal. Biodivers Conserv. 2006;15:631-46.

41. Scales BR, Marsden SJ. Biodiversity in small-scale tropical agroforests: a review of species richness and abundance shifts and the factors influencing them. Environ Conserv. 2008:35:160-72.

42. Parra F, Casas A, Peñaloza-Ramírez JM, Cortés Palomec AC, Rocha Ramírez V, González-Rodríguez A. Evolution under domestication: ongoing artificial selection and divergence of wild and managed Stenocereus pruinosus (Cactaceae) populations in the Tehuacán Valley, Mexico. Ann Bot-London. 2010;106(3):483-96.

43. Parra F, Blancas J, Casas A. Landscape management and domestication of Stenocereus pruinosus (Cactaceae) in the Tehuacán Valley: human guided selection and gene flow. J Ethnobiol Ethnomed. 2012;8:32.

44. Swift MJ, Vandermeer J, Ramakrishnan PS, Anderson JM, Ong CK, Hawkins BA. In: Mooney HA, Cushman JH, Medina E, Sala O, Schulze ED, editors. Biodiversity and Agroecosystem Function. Fuctional Roles of Biodiversity: A Global Perspective. Chichester, New York, Brisbane, Toronto and Singapore: Wiley; 1996. p. 262-94

45. Blanckaert I, Vancraeynest K, Swennen RL, Espinosa-García FJ, Piñero D, Lira R. Non-crop resources and the role of indigenous knowledge in semiarid production of Mexico. Agri Ecosyst Environ. 2007;119:39-48.
46. Blancas J, Casas A, Pérez-Salicrup D, Caballero J, Vega E. Ecological and sociocultural factors influencing plant management in Nahuatl communities of the Tehuacan Valley, Mexico. J Ethnobiol Ethnomed. 2013;9(1):39.

47. Moreno-Calles A, Casas A, García-Frapolli E, Torres-García I. Traditional agroforestry systems of multi-crop "milpa" and "chichipera" cactus forest in the arid Tehuacán Valley, Mexico: their management and role in people's subsistence. Agrofor Syst. 2012;84(2):207-26.

48. Larios C, Casas A, Vallejo M, Moreno-Calles Al, Blancas J. Plant management and biodiversity conservation in Náhuatl homegardens of the Tehuacán Valley, Mexico. J Ethnobiol Ethnomed. 2013;9:74.

49. Vallejo M, Casas A, Blancas J, Moreno-Calles Al, Solís L, Rangel-Landa S, Dávila P, Tellez O. Agroforestry systems in the highlands of the Tehuacán Valley, Mexico: Indigenous culture and biodiversity conservation. Agrofor Syst. 2014;88:125-40.

50. Altieri M, Nicholls C. Teoría y práctica para una agricultura sostenible. Serie de Textos Básicos para la Formación Ambiental. Programa de las Naciones Unidas para el Medio Ambiente. México: Red de Formación ambiental para América Latina y el Caribe; 2000.

51. Perfecto I, Armbrecht I, Philpott SM, Soto-Pinto L, Dietsch TM. Shaded coffee and the stability of rainforest margins in northern Latin America. The Stability of Tropical Rainforest Margins, Linking Ecological, Economic and Social Constraints of Land Use and Conservation. In: Tscharntke T, Leuschner C, Zeller M, Guhadja E, Bidin A, editors. Environmental Science Series. Berlin: Springer Verlag; 2007. p. 227-64.

52. Chazdon RL. Tropical forest recovery: legacies of human impact and natural disturbances. Perspect Plant Ecol. 2003;6:51-71.

53. Harvey CA, Medina A, Sánchez Merlo D, Vílchez S, Hernández B, Saenz J, Maes J, Casanovas F, Sinclair FL. Patterns of animal diversity associated with different forms of tree cover retained in agricultural landscapes. Ecol Appl. 2006:16:1986-99.

54. Nabhan GP, Amadeo MR, Reichhardt KL, Mellink E, Hutchinson CF. Papago influences on habitat and biotic diversity: Quitovac oasis ethnoecology. J Ethnobiol. 1982;2:124-43.

55. Montagnini F. Homegardens of Mesoamerica: biodiversity, food security, and nutrient management. In: Kumar BM, Nair PKR, editors. Tropical Homegardens: A Time-Tested Example of Sustainable Agroforestry. The Netherlands: Springer; 2006. p. 1-23.

56. Vallejo M, Casas A, Pérez-Negrón E, Moreno-Calles Al, Hernández-Ordoñez O, Tellez O, Dávila P. Agroforestry systems of the lowland alluvial valleys of the Tehuacan-Cuicatlan biosphere reserve: an evaluation of their biocultural capacity. J Ethnobiol Ethnomed. 2015;11:8.

57. Armbrecht I, Rivera L, Perfecto I. Reduced Diversity and Complexity in the Leaf-Litter Ant Assemblage of Colombian Coffee Plantations. Conserv Biol. 2005;9(3):897-907

58. Tougiani A, Guero C, Rinaudo T. Community mobilisation for improved livelihoods through tree crop management in Niger. GeoJ. 2009;74(5):377-89.

59. MacNeish RS. A summary of subsistence. In: Byers DS, editor. The prehistory of the Tehuacán Valley: Enviroment and Subsistence vo1.1. Austin: University of Texas Press; 1967. p. 290-309.

60. Smith CE. Flora, Tehuacán Valley. Chicago Natural History Museum. 1965.

61. Perfecto I, Snelling R. Biodiversity and the transformation of a tropical agroecosystem: ants in coffee plantations. Ecol Appl. 1995;5:1084-97.

62. Oke DO, Odebiyi KA. Traditional cocoa-based agroforestry and forest species conservation in Ondo State, Nigeria. Agri Ecosyst Environ. 2007;122:305-11.

63. Okubo S, Harashina K, Muhamad D, Abdoellah OS, Takeuchi K. Traditional perennial crop-based agroforestry in West Java: the tradeoff between onfarm biodiversity and income. Agrofor Syst. 2010;80:17-31.

64. Schroth G, Faria D, Araujo M, Bede L, Van Bael SA, Cassano CR, Oliveira LC, Delabie JH. Conservation in tropical landscape mosaics: the case of the cacao landscape of southern Bahia, Brazil. Biodivers Conserv. 2011;20(8):1635-54.

65. Ford A, Nigh R. Origins of the Maya forest garden: Maya resource management. J Ethnobiol. 2009;29(2):213-36.

66. Toledo VM, Moguel P. Coffee and sustainability: the multiple values of traditional shaded coffee. J Sustain Agr. 2012;36(3):353-77.

67. Tilman D, Cassman KG, Matson PA, Naylor R, Polasky S. Agricultural sustainability and intensive production practices. Nature. 2002;418(6898): $671-7$.

68. Steffan-Dewenter I, Kessler M, Barkmann J, Bos MM, Buchori D, Erasmi S, et al. Tradeoffs between income, biodiversity, and ecosystem functioning during tropical rainforest conversion and agroforestry intensification. Proc Natl Acad Sci U S A. 2007;104:4973-8. 
69. Millennium Ecosystem Assessment. Ecosystems and Human Well-being: Desertification Synthesis. Washington, DC: World Resources Institute; 2005

70. FAO (Food and Agriculture Organization). State of the world's forests. Rome: FAO; 2005.

71. Izac A, Sanchez PA. Towards a natural resource management paradigm for international agriculture: the example of agroforestry research. Agr Syst. 2001;69:5-25

72. Leakey R. Agroforestry for Biodiversity in Farmin Systems. In: Colling W, Qyalset C, editors. Biodiversity in Agroecosystems. NY: Lewis Publishers; 1999. EU.

73. Marie CN, Sibelet N, Dulcire M, Rafalimaro M, Danthu P, Carrière SM. Taking into account local practices and indigenous knowledge in an emergency conservation context in Madagascar. Biodiv Conserv. 2009;18(10):2759-77.

74. Asase A, Tetteh DA. The role of complex agroforestry systems in the conservation of forest tree diversity and structure in southeastern Ghana. Agrofor Syst. 2010;79:355-68.

75. Perfecto I, Armbrecht I. The coffee agroecosystem in the Neotropics: Combining ecological and economic goals. In: Vandermeer J, editor. Tropical Agroecosystems. Boca Raton: CRC Press; 2003. p. 159-94.

76. Quinkenstein A, Wöllecke J, Böhm C, Grunewald H, Freese D, Schneider BU, Huttl RF. Ecological benefits of the alley cropping agroforestry system in sensitive regions of Europe. Environ Sci Policy. 2009;12(8):1112-21.

77. Thevathasan NV, Gordon AM, Bradley R, Cogliastro A, Folkard P, Grant R, Kort J, Liggins F, Njenga F, Olivier A, Pharo C, Powell G, Rivest D, Schiks T, Trotter, Van Rees K, Whalen J, Zabek L. Agroforestry research and development in Canada: the way forward. In: Agroforestry-The Future of Global Land Use. Netherlands: Springer; 2012. p. 247-83.

78. Budowski G. El alcance y el potencial de la agroforestería con énfasis en Centroamérica. In: Krishnamurthy L, Leos JA, editors. Agroforestería en Desarrollo, Educación: Investigación y Extensión. Centro de Agroforestería para el desarrollo sostenible. México: UACh; 1994. p. 1-16.

79. Jose S, Gillespie AR, Pallardy SG. Interspecific interactions in temperate agroforestry. Agrofor Syst. 2004;61:237-55.

80. Dupraz C, Newman SM. Temperate agroforestry: the European way. In: Gordon AM, Newman SM, editors. Temperate agroforestry systems. Wallingford: CAB International; 1997. p. 181-236.

81. Herzog F. Streuobst: a traditional agroforestry system as a model for agroforestry development in temperate Europe. Agrofor Syst. 1998;42:61-80

82. Plieninger T, Schaar M. Modification of land cover in a traditional agroforestry system in Spain: processes of tree expansion and regression. Ecol Soc. 2008;13(2):25.

83. Sharma AK, Gupta JP. Agroforestry systems for the hot arid regions of India. In proceedings of IUFRO-DNAES Conference on Resource Inventory Techniques to support agroforestry and environment activities. October 1-3. Chandigarh. pp. 259-262. 1996.

84. McNeely JA. Biodiversity in arid regions: value and perceptions. J Arid Environ. 2003;54:61-70.

85. Moreno-Calles Al, Casas A. Conservación de biodiversidad y sustentabilidad en sistemas agroforestales de zonas áridas del valle de Tehuacán, México. Zonas Áridas. 2008;12(1):13-35.

86. Whitfield S, Reed MS. Participatory environmental assessment in drylands: introducing a new approach. J Arid Environ. 2012;77:1-10.

87. Tewari VP, Arya R. Degradation of arid rangelands in Thar Desert, India: A review. Arid Land Res Manag. 2004;19(1):1-12.

88. Casas A, Cruse J, Morales E, Otero-Arnaiz A, Valiente-Banuet A. Maintenance of phenotypic and genotypic diversity of Stenocereus stellatus (Cactaceae) by indigenous peoples in Central México. Biodiv Conserv. 2006;15:879-98.

89. Blancas JJ, Parra F, Lucio JD. Manejo tradicional y consenvación de la biodiversidad de Polaskia spp. (Cactaceae) en México. Zonas Áridas. 2006;10:20-40.

90. Parra F, Pérez-Nasser N, Peréz Salicrup D, Lira R, Casas A. Populations genetics and process of domestication of Stenocereus pruinosus in the Tehuacán Valley, México. J Arid Environ. 2008;72:1997-2010.

91. Sonwa DJ, Nkongmeneck BA, Weise SF, Tchatat M, Adesina AA, Janssens MJJ. Diversity of plants in cocoa agroforests in the humid forest zone of Southern Cameroon Biodivers. Conserv. 2007; 16: 2385-2400.

\section{Submit your next manuscript to BioMed Central and we will help you at every step:}

- We accept pre-submission inquiries

- Our selector tool helps you to find the most relevant journal

- We provide round the clock customer support

- Convenient online submission

- Thorough peer review

- Inclusion in PubMed and all major indexing services

- Maximum visibility for your research

Submit your manuscript at www.biomedcentral.com/submit 